\title{
Implementation of Google Classroom as Multimedia Learning
}

\author{
Anderias Henukh ${ }^{1}$, Haris Rosdianto ${ }^{2}$, Sayaka Oikawa ${ }^{3}$ \\ Universitas Musamus, Indonesia ${ }^{1}$, STKIP Singkawang, Indonesia ${ }^{2}$, Hirosaki University, Japan $^{3}$ \\ henukh_fkip@unmus.ac.id ${ }^{1}$, harisrosdianto@yahoo.com ${ }^{2}$, sayaka.hime17@gmail.com ${ }^{3}$
}

Received: December $23^{\text {th }}, 2019$. Revised: January $16^{\text {th }}, 2020$. Accepted: February $2^{\text {nd }}, 2020$

\section{Keywords : \\ Google Classroom; \\ Multimedia Learning}

\begin{abstract}
This research was carried out at Musamus University in academic year 2019/2020 by taking a basic physics class I as a research sample. The purpose of this research is to determine the effectiveness of the implementation of Google classroom as multimedia learning. The research method used in this research is descriptive qualitative supported by quantitative data. The instrument used was a material and multimedia expert validation sheet, questions that had been validated to test the effectiveness of implementing Google classroom as learning multimedia. Based on the description above it can be concluded that the implementation of google classroom as multimedia learning with average results of multimedia expert validation of $82.5 \%$ and $87 \%$ of material experts have a good impact on the learning process and outcomes of students. This is evidenced by an increase in the value of each student with average of pre-test score is 62 and post-test score is 83. N-gain score is 0,75 (high category).
\end{abstract}

\section{INTRODUCTION}

In the current 4.0 industrial revolution era, various types of human needs are mostly met by online-based systems. Very many applications have been made to facilitate or accelerate access to jobs and human needs, as well as in the world of education. Many online applications are utilized in the world of education, such as school and campus webs, academic information systems, and others [1]. In addition, there are online applications that are used in learning systems, for example by creating e-learning applications. The application can be made as you wish with the help of a programmer, or use e-learning services that have been provided by several developers. From several e-learning applications that are open source, Google Classroom application is an application that has been used also as e-learning. In addition, in the world of education on campus, this application can also be used as multimedia learning. Multimedia is the use of some media in the form of text, graphics, animation, images, video, and sound to convey information, messages or material to users so that it seems interesting [2]. In this study more emphasis on the implementation of Google classroom learning multimedia.

Google classroom is a foyer of learning that can be devoted to any scope of education intended to help find a way out of the difficulties experienced in making assignments without using paper [3-4]. The utilization of Google Classroom can be via multiplatform that is through computers and devices. 
Educators and students can visit the site https://classroom.google.com or can download applications through PlayStore on Android or through the App Store on iOS with the Google Classroom keyword. The use is free of charge so that its utilization can be done as needed so this makes Google Classroom easily accessible.

The use of Google Classroom will make learning more effective, moreover, educators and students can face to face at any time through Google classroom online classes [4]. Material uploaded to the classwork bar can be the word, excel, powerpoint, pdf, simulation or video files. The material provided in this implementation also relates to the daily lives of students [5]. This is done by educators to accommodate the differences in the speed of thinking, background knowledge, and differences in students' learning styles. To start using google classroom we first enter a google account and then search for the google product. after logging in to the google classroom account we are confronted with three main menus namely streams, classwork or student activities, and people. The stream is a google classroom facility that can be used to create announcements, discuss ideas or see the flow of assignments, materials, quizzes from the topics being taught.

Classwork can be used by educators to make test questions, pretests, quizzes, upload material and hold reflections. In the people menu, the educator can invite students by using the access code that is available in the people bar, while to invite other educators as collaborators simply by inviting educators through their respective emails. As multimedia learning, google classroom has been proven to support the success of teaching and learning because it can be integrated with any model or method [6].

The experience found during the learning process is the inadequate mastery of technology from the students so that it becomes the basis for implementing google classroom as multimedia learning. Before implementing, students are given assistance and tutorials on using Google classroom first, so they have no difficulty in using it. This is very important because mastery of multimedia learning is a must in industrial 4.0 era. In the assessment section also used formative assessment so that it can improve student learning outcomes [7].

Based on the description above, a study with the title "Implementation of google classroom as multimedia learning" by taking a basic physics class I as a case study. The purpose of this research is to determine the effectiveness of the implementation of Google classroom as multimedia .

\section{METHOD}

This research was carried out at Musamus University in the 2019/2020 school year by taking a basic physics class I as a research sample. The research method used in this research is descriptive qualitative supported by quantitative data. In this study, work and energy teaching materials were developed in the basic physics course I, then validation of material and multimedia experts and product effectiveness tests were integrated with Google classroom. The instruments used were questionnaires and questions validated using the product moment formula [8] and reliability using the KR-20 formula [9].

Data analysis was performed using a Likert scale to measure people's opinions and perceptions [9]. In determining the percentage of success used equation (1).

Where: $p$ : Percentage of success (\%)

$$
p=\frac{s}{n} \times 100 \%
$$

$s$ : The amount of the acquisition value

$n$ : The maximum number of values

The data obtained were then written down on the interpretation of the scores below [9]. 
Tabel 1. Likert Scale

\begin{tabular}{cc}
\hline Average score & Interpretation \\
\hline $0 \%-20 \%$ & Not Good \\
$21 \%-40 \%$ & Less Good \\
$41 \%-60 \%$ & Enough \\
$61 \%-80 \%$ & Goog \\
$81 \%-100 \%$ & Very Good \\
\hline
\end{tabular}

Analysis of the improvement in students' abilities after participating in learning with $\mathrm{N}$-gain calculated using equation (2) as follows [10].

$$
N-\text { Gain }=\frac{\text { Posttest score }- \text { pretest score }}{\text { maximum score-pretest score }}
$$

The results of the $\mathrm{N}$-gain calculation were categorized into 3 (three) categories [2], as table below.

Table 2. N-Gain Categorized

\begin{tabular}{cc}
\hline Category & Value \\
\hline High & $\mathrm{N}$-gain $>0,7$ \\
Medium & $0.3 \leq \mathrm{N}$-gain $\geq 0.7$ \\
Low & $\mathrm{N}$-gain $<0.3$ \\
\hline
\end{tabular}

\section{RESULTS AND DISCUSSIONS}

A material feasibility test was conducted by two multimedia experts. The feasibility test was carried out with a questionnaire with 15 questions consisting of text, graphics, images, video, and sound. After the aspects are tested or assessed and examined by the examiner, an assessment is given. The results of the material feasibility test are displayed in the following graph.

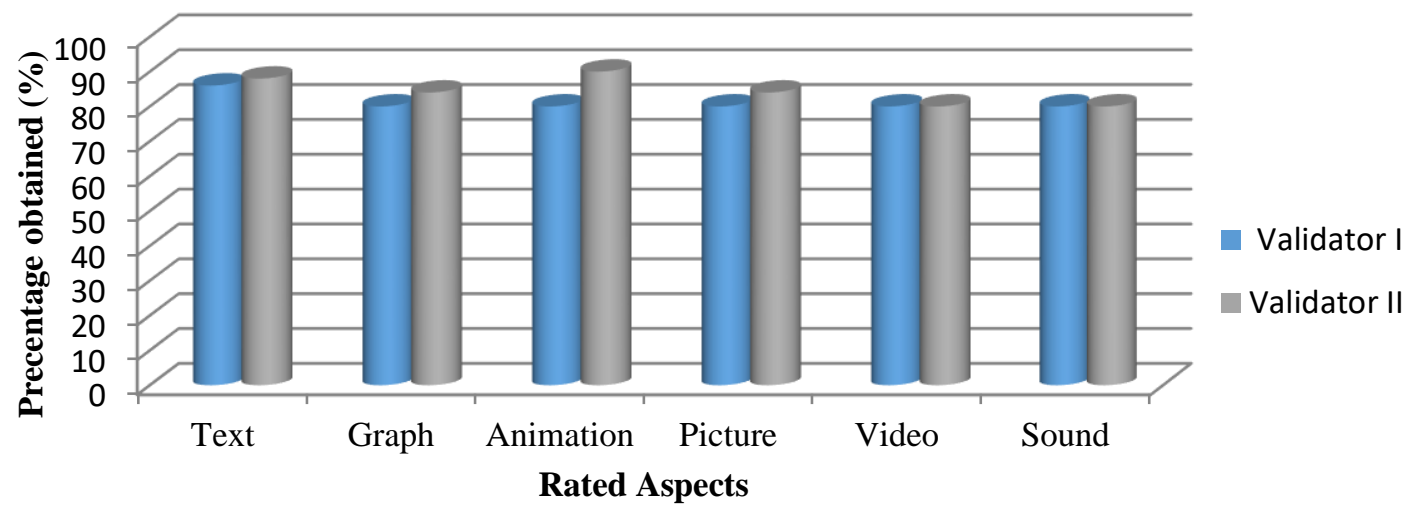

Fig 1. Results of the multimedia expert feasibility test

Based on the graph above, it was concluded that this material obtained the results of eligibility on the first examiner on average by $81 \%$, while for the feasibility test on the second examiner that was equal to $84 \%$. Then the overall presentation for the percentage of media feasibility test is $82.5 \%$. With the percentage obtained, the feasibility of the material in the range of $81 \%-100 \%$, so based on [9] obtained very good criteria.

A material feasibility test is carried out by two material experts. The feasibility test was carried out with a questionnaire with 15 questions covering the curriculum, basic competencies, lecture material, 
material content, and evaluation containing 10 items. The results of the material feasibility test are displayed in the following graph.

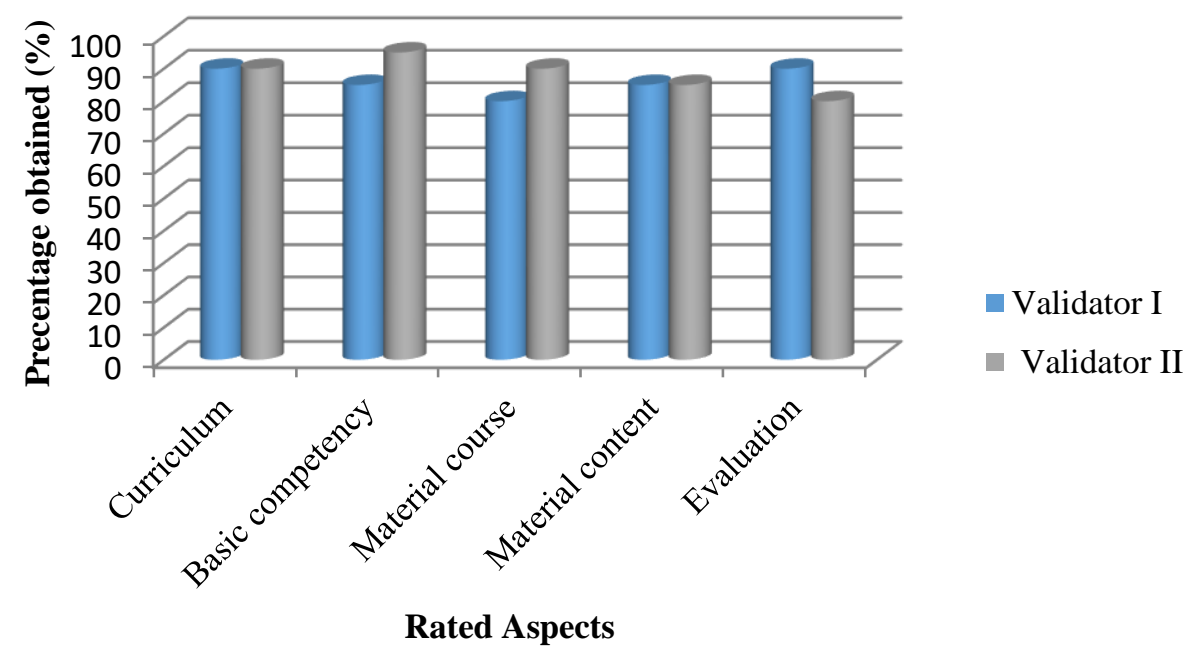

Fig 2. Results of the material expert feasibility test

Based on the graph above, it was concluded that this material obtained the results of eligibility in the first examiner an average of $86 \%$, while for the feasibility test the second examiner was $88 \%$. So the overall presentation for the percentage of material feasibility test is $87 \%$. With the percentage obtained, the feasibility of the material in the range of $81 \%-100 \%$, so based on a Likert scale [9] obtained very good criteria. The implementation of Google classroom can be seen in the following figure.

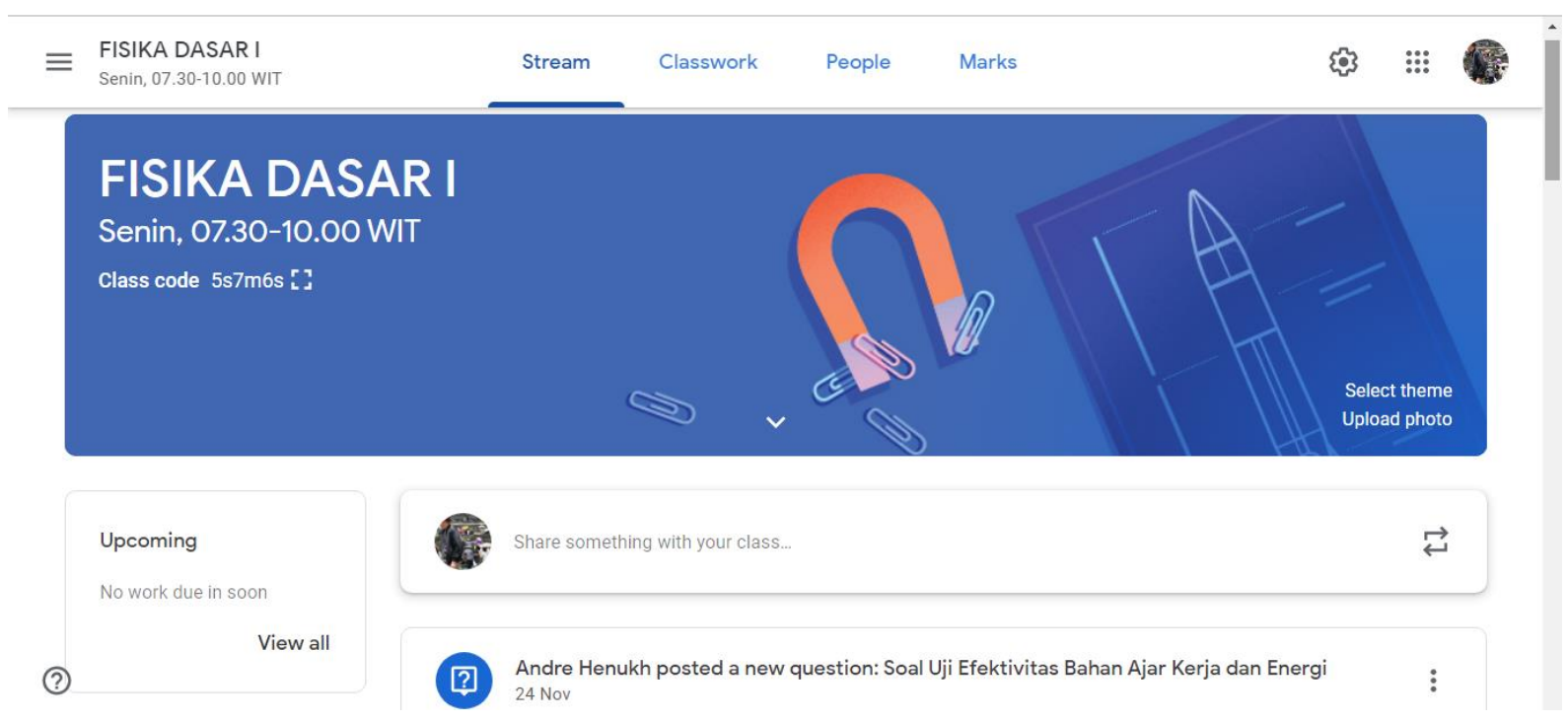

Fig 3. Basic physics class

The material provided in the form of video, ppt, simulation, and material files in pdf format can be seen in the following image bellow. 
Implementation of Google Classroom as Multimedia Learning Anderias Henukh, Haris Rosdianto, Sayaka Oikawa

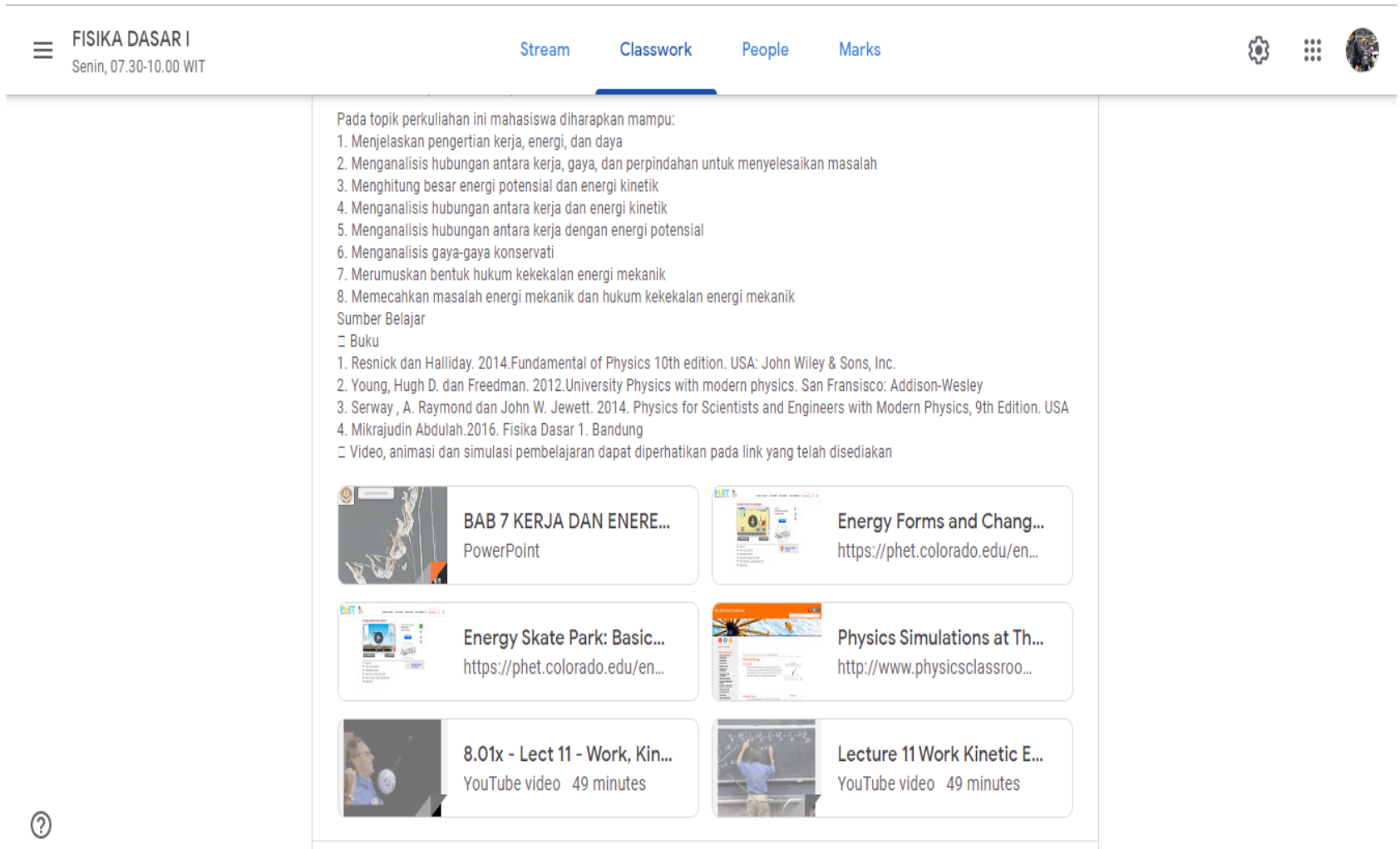

Fig 4. Materials in google classroom

In addition to the various materials available in the picture above, the learning objectives are also conveyed so that learning done through multimedia Google classroom learning becomes focused because it has clear goals.

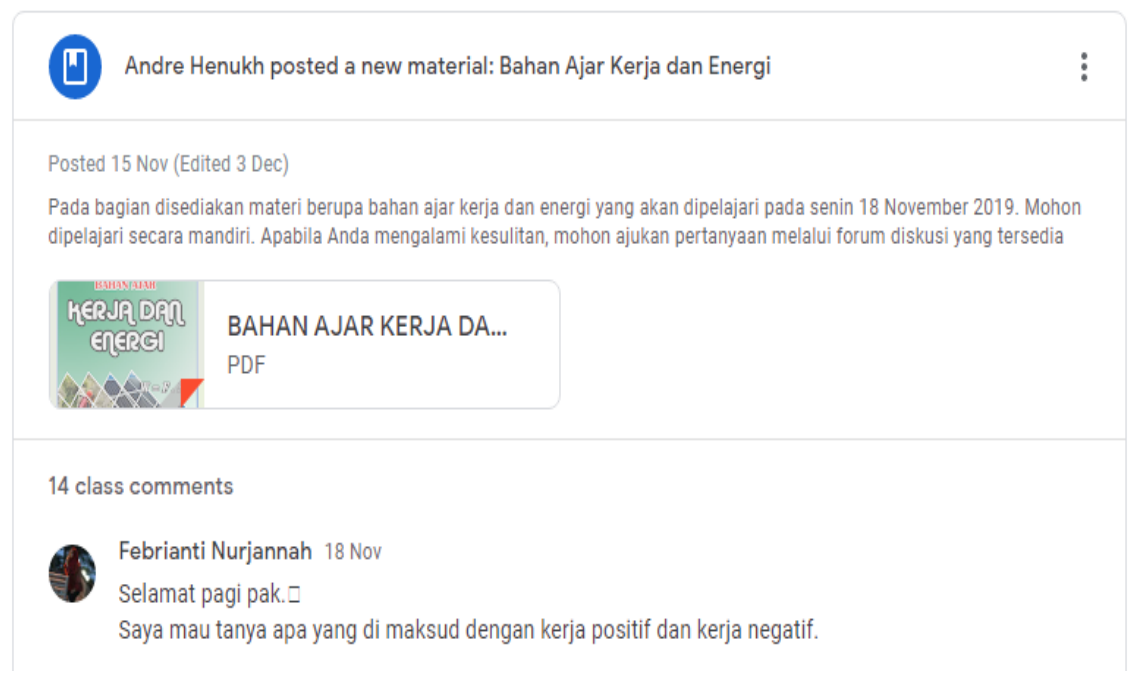

Fig 5. Material (pdf) and conversation in google classroom

The picture above shows the material of work and energy in the form of pdf files. In the material section there are interactions between educators and students as well as between students. This interaction is very important in helping students to understand learning material that is not yet understood so that learning objectives can be achieved. 
The results of testing the effectiveness of using instruments in the form of questions that have been validated and reliability of students in physics class 1, obtained values with an average pretest 62 and posttest 83 . This has prepared a variety of learning resources that can be accessed directly by students. Besides they can also conduct discussions through google classroom so that their knowledge is increasing. This can be seen in the following table.

Table 3. Effectiveness Test Results

\begin{tabular}{ccc}
\hline Responden & Pretest score & Posttest score \\
\hline 1 & 65 & 86 \\
2 & 65 & 90 \\
3 & 65 & 90 \\
4 & 65 & 86 \\
5 & 60 & 86 \\
6 & 60 & 86 \\
7 & 60 & 86 \\
8 & 60 & 86 \\
9 & 60 & 82 \\
10 & 60 & 82 \\
11 & 60 & 85 \\
12 & 60 & 70 \\
13 & 60 & 70 \\
\hline Average & $\mathbf{6 2}$ & $\mathbf{8 3}$ \\
\hline
\end{tabular}

Barriers experienced in implementing the stages of implementing Google classroom as multimedia learning are students who are not yet familiar with using Google classroom. Besides, there are 2 students do not have an Android phone or laptop so they have difficulty accessing or using Google Classroom. Another obstacle is the availability of internet quota. Some students do not have a quota in accessing the internet.

The solution offered to overcome the problem above is to inform again and teach the steps or procedures to use Google Classroom to students. Also, students who do not have an Android cellphone or laptop are given the opportunity for them to borrow from their friends or relatives. The problem of internet quota is overcome by asking students to access the material in the campus area and or public areas that provide free hotspot or wifi facilities. Besides, they can ask tethering to their friends.

The features offered by Google Classroom are providing classrooms without paper, access to other Google products such as Gmail, Google Drive, Google Form, and collaboration between teachers and students outside the classroom, easy to manage, save money, and for teachers to better track student progress. This is a distinct advantage compared to other e-learning platforms. Besides the advantages in this study compared to previous research conducted is the provision of complete learning materials including videos, simulations, PPT and Pdf so as to facilitate students in achieving learning objectives.

\section{CONCLUSION AND SUGGESTION}

Based on the description above it can be concluded that the implementation of google classroom as multimedia learning with average results of multimedia expert validation of $82.5 \%$ and $87 \%$ of material experts have a good impact on the learning process and outcomes of students. This is evidenced by an increase in the value of each student with average pre-test score 62 and post-test score of 83 . N-gain score 0,75 (high category). The suggestion for further research is the need for students' initial understanding of the function of the google classroom and the menus in it so that during their implementation they do not experience difficulties. 


\section{REFERENCES}

[1] Asnawi, N. (2018). Pengukuran Usability Aplikasi Google Classroom Sebagai E-learning Menggunakan USE Questionnaire (Studi Kasus: Prodi Sistem Informasi UNIPMA). RESEARCH: Computer, Information System \& Technology Management, 1(1): 17-21.

[2] Henukh, A., Nikat, R. F., Simbolon, M., Nuryadin, C., \& Baso, Y. S. (2019, October). Multimedia development based on web connected Massive Open Online Courses (cMOOCs) on the basic physics material. In IOP Conference Series: Earth and Environmental Science (Vol. 343, No. 1, p. 012160). IOP Publishing.

[3] Gunawan, F. I., \& Sunarman, S. G. (2018, February). Pengembangan Kelas Virtual Dengan Google Classroom Dalam Keterampilan Pemecahan Masalah (Problem Solving) Topik Vektor Pada Siswa SMK Untuk Mendukung Pembelajaran. In Prosiding Seminar Nasional Pendidikan Matematika Etnomatnesia.

[4] Soni, S., Hafid, A., Hayami, R., Fatma, Y., Wenando, F. A., Al Amien, J., ... \& Hasanuddin, H. (2018). Optimalisasi Penggunaan Google Classroom, E-Learning \& Blended Learning Sebagai Media Pembelajaran Bagi Guru Dan Siswa Di SMK Negeri 1 Bangkinang. Jurnal Pengabdian UntukMu NegeRI, 2(1): 17-20.

[5] Henukh, A., Simbolon, M., \& Budiman, N. A. (2019). Deskripsi Sistem Pembelajaran Fisika Melalui Pendekatan Kontekstual. Musamus Journal of Science Education, 2(1): 22-30.

[6] Ernawati, M. (2018). Media Pembelajaran Google Classroom. Kompas. Jakarta, December 18th.

[7] Nikat, R. F., Munfarikha, N., \& Henukh, A. (2019, October). Implementation e-learning as a formative assessment to explore mastery concept's student on magnetic field material. In IOP Conference Series: Earth and Environmental Science (Vol. 343, No. 1, p. 012214). IOP Publishing.

[8] Widiyanto, M. A. (2014). Statistika. Jakarta: Kalam Hidup.

[9] Sugiyono. (2015). Metode Penelitian Pendidikan. Bandung: Alfabeta.

[10] Marzuki, A. (2019, February). The development of students worksheet based on Predict, Observe, Explain (POE) to improve students' science process skill in SMA Muhammadiyah Imogiri. In Journal of Physics: Conference Series (Vol. 1153, No. 1, p. 012148). IOP Publishing. 